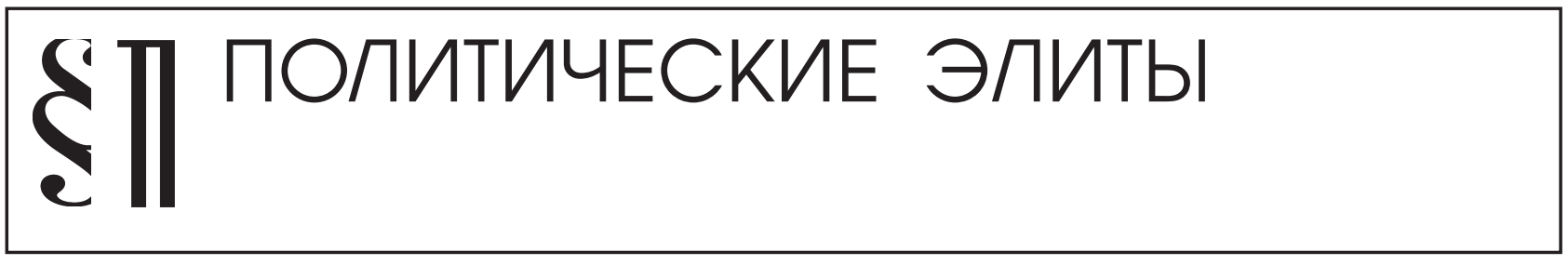

Волков М.С.

\title{
ПРАВЯЩАЯ ЭЛИТА ИСПАНИИ В ГОДЫ КОНСОЛИДАЦИИ ДЕМОКРАТИИ
}

Аннотация: Статья посвящена изучению социальных характеристик испанской правящей элиты в конце 1970-х1990-х годах, в период нахождения у власти Испанской сочиалистической рабочей партии. Это время характеризуется учеными-испанистами как период консолидаиии демократии. На основе массового биографического материала автором анализируется состав испанской правящей элиты и ее отдельных групп по основным соииальным характеристикам, таким как: место рождения, возраст, образование и тип карьеры. В работе делается попытка определить, насколько радикальными стали перемены в общественно-политической жизни страны в результате падения диктатуры генерала Франсиско Франко и как эти события повлияли на процесс обновления правящей элиты Испании. В статье рассматривается также политика, проводимая социалистами в отношении государственного аппарата и армейского руководства страны, а также выявлена роль новой правящей элиты, ее компетенция и эффективность управления страной.

Review: The article is devoted to studying social characteristics of Spain ruling elite at late 1970's - 1990's when the Spain socialistic workers' party was governing. Spanish researchers describe those times as the period of democracy consolidation. Based on massive biography data, the author analyzes members of Spanish ruling elite according to the main social characteristics such as place of birth, age, education and career. The author of the article makes an attempt to define how radical social and political transformations were after the failure of Francisco Franco's government and how it influenced the process of renewal of the ruling elite of Spain. The author of the article also views the policy undertaken by socialists in relation to state government and army leadership of the country. The author also describes the role of the new ruling elite, their competence and efficiency.

Ключевые слова: элита, Испания, сочиальные характеристики, демократия, социалисты, кортесы, министры, государственный аппарат, генералитет, ИСРП

Keywords: elite, Spain, social characteristics, democracy, socialists, Cortes, ministers, state government, general officers, Integrated Standby Instrument Systems.

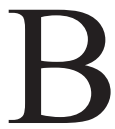
результате парламентских выборов 1982 г. почти на полтора десятилетия власть в Испании перешла к социалистам, причем, получив на этих выборах $48 \%$ голосов (а также $43 \%$ на последовавших в следующем году муниципальных), они обеспечили себе абсолютное большинство в обеих палатах Кортесов и, соответственно, полную свободу рук в проведении своей политики. Поэтому их победа знаменовала качественно новый этап политического развития страны. Во главе правительства встал Ф. Гонсалес Маркес.

Социально-экономическая политика социалистов была абсолютно прагматичной и не предусматривала даже тех мер, которые пытались провести социалистические правительства других европейских стран; Ф. Гонсалес вполне отдавал себе отчет в том, что «ИСРП опиралась на большинство, считавшее абсолютно первоочередной задачей укрепление демократии и не признававшее национализации» ${ }^{1}$. Основные усилия социалистов были направлены на упрочение демократической политической системы с целью сделать ее необратимой, и этой же цели была целиком подчинена и внешняя политика социалистов. Они приложили все силы, чтобы исход референдума 12 марта 1986 г. по вопросу вступления в военную организацию НАТО оказался положительным. Руководство социалистов хорошо понимало, что интеграция ис-

\footnotetext{
${ }^{1}$ Matin. 1985.20 nov.
} 
панской армии в военные структуры Запада неминуемо изменит традиционное положение армии в стране и послужит гарантией от новых попыток военного переворота.

Поскольку для Испании этот вопрос всегда был крайне болезненным, на политике социалистов в отношении армии следует остановиться подробнее. В результате проводимых с 1977 г. реформ вместо трех военных постов - министров сухопутных сил, ВВС и ВМС было образовано единое Министерство обороны во главе с гражданским лицом. Численность армии была сокращена с 250 до 160 тысяч человек, количество генеральских должностей было уменьшено в 2 раза, а офицеры старших возрастов были отправлены в отставку ${ }^{2}$. Численность основных структурных частей системы охраны общественного порядка составляла 132 тыс. человек (70 тыс. в Гражданской гвардии, 50 тыс. в Национальной полиции и 12 тыс. в Высшем полицейском корпусе) $)^{3}$.

Главный итог деятельности реформаторов, а в особенной степени социалистов после их полной победы на выборах 1982 г., состоял в том, что армия в лице ее высшего руководства фактически была лишена всякого влияния на политическую жизнь страны и таким образом произошел полный разрыв с предшествующей традицией не только франкистского режима, но и более ранних времен, когда армия была важнейшим компонентом политической системы, а генералитет - специфической частью общеполитической элиты. Отныне же генералитет лишился этой своей традиционной роли.

Для того чтобы оценить, насколько радикальной была чистка военного руководства при приходе к власти социалистов (и, соответственно, слом традиционной роли генералитета), посмотрим, что представлял собой состав испанского генералитета на середину 80-х годов (конец 1984 - начало 1985 гг.). В официальных изданиях ${ }^{4}$ фигурируют около 60 представителей командования армии, флота и Гражданской гвардии. Что же это были за люди?

Разумеется, социалистам неоткуда было взять «своих» генералов, им приходилось выбирать из того офицерского состава, который остался со вре-

2 Данилевич И.В. Испытание властью: Испанская социалистическая рабочая партия в 80-е годы. М., 1991. С. 77.

${ }^{3}$ Современная Испания. Отв. ред. В.В.Загладин. М.,1983. C. 222.

${ }^{4}$ См.: Quien es quien en Espana. Madrid, 1985. мен правления Франко. По возрасту это были весьма зрелые, и даже пожилые люди: ни один из них не был моложе 50 лет, и лишь 10 человек (17,5\%) были моложе 60. Все остальные 47 человек или $82,5 \%$ были старше 60 лет (1918-1924 годов рождения), в том числе 9 человек - старше 65 лет. 23 представителя генералитета - 40,5\% начали карьеру еще в годы гражданской войны (в 1936-1939 гг.), еще 29 (56,1\%) - в годы Второй мировой войны (в 1941-1945 гг.) и только двое (3,5\%) поступили на службу в 1951 г. То есть все это были старые франкистские офицеры. Службу они начинали в весьма юном возрасте: 18 человек (из 53 , у кого есть данные о годе поступления на службу) поступили добровольцами, когда им еще не исполнилось 18 лет (10 - в возрасте 17 лет, 7 - в возрасте 16 лет и один даже в 15-тилетнем возрасте; все они были добровольцами армии Франко времен гражданской войны), 33 человека (62,3\%) поступили на службу в возрасте 18-20 лет (из них 19 чел. - в возрасте 19 лет), и двое (3,8\%) - позже (в возрасте 21 и 26 лет). Из этих лиц 10 чел. или 17,5\% окончили военные училища, 32 чел. или 56,1\% - затем и Высшую военную академию, 8 чел. (14\%) - и гражданские вузы (4 юриста, 2 экономиста, 1 естественник и 1 гуманитарий), двое имели докторскую степень.

Однако из офицерского корпуса времен Франко новыми властями были отобраны и вознесены на вершину иерархии только те лица, которые были сочтены наиболее лояльными и не имеющими политических амбиций. То есть это были старые офицеры, но очень «молодые» генералы. Достаточно сказать, что только 6 человек $(11,1 \%)$ стали генералами при правлении Франко, тогда как 34 (63\%) получили первый генеральский чин уже после его смерти - в 1976-1981 гг,, а 14 человек - свыше четверти $(25,9 \%)$ - так и вообще после прихода к власти социалистов - в течение последних трех лет (в 1982-1984 гг.). Еще более показательно время присвоения этим лицам их последнего (более высокого) генеральского чина: 53 из 57 человек - 96,5\% получили его в 1982-1984 гг., уже при социалистах (а остальные четверо лишь двумя годами ранее), причем 21 человек $(36,8 \%)$ - в 1984 году. То есть эти люди сделали молниеносную карьеру уже при социалистах.

Это тем более примечательно, что при Франко они выслуживали старшие офицерские чины по многу лет. Например, генеральный инспектор Национальной полиции Ф. Алькала-Галиано Перес 


\section{Политика и общество 10 (106) 2013}

стал майором в 1961 г., подполковником в 1974 (через 13 лет), полковником в 1978 (через 4 года), а два генеральских чина прошел за 6 лет (произведен в бригадные генералы в 1981, в генерал-майоры в 1984 г.); командующий 8-м военным округом Х. Буйгуес Гомес был майором еще с 1952 г., зато, став в 1981 г. бригадным генералом, уже в 1982 г. получил чин генерал-майора, а в 1984 - генераллейтенанта; командир 2-й механизированной дивизии А. Кентено Перес от капитана до полковника служил 28 лет (с 1950 до 1978), а два генеральских чина прошел за 5 лет (бригадный генерал с 1981 г. и генерал-майор с 1983 г.); командующий войсками на Балеарских островах Д. Хименес Риуторд от капитана до подполковника служил 23 года (19491972), а от бригадного генерала до генерал-майора - 3 года (1981-1983); командир 3-й механизированной дивизии Р. Мартин Амбросио от капитана до полковника служил 28 лет (1950-1978), а два генеральских чина прошел за 5 лет (бригадный генерал с 1981 г. и генерал-майор с 1983 г.); командир 5-й горной дивизии Ф. Планас Корсини стал капитаном в 1950 г., майором в 1961 г. (11 лет), полковником в 1978 г. (17 лет), а два генеральских чина прошел за 6 лет (бригадный генерал с 1981 г. и генерал-майор с 1984 г.); Ф. Родригес Вентоса от капитана до бригадного генерала служил 32 года (19491981), но генерал-майора получил уже в 1982 г., а генерал-лейтенанта в 1984 г.

Очень быструю карьеру, пройдя два генеральских чина за 2-3 года, сделали произведенные в первый генеральский чин уже в 80-х годах и при социалистах генерал-лейтенанты Р. Кастелло дель Рио (председатель Главного военного суда), Г. Уррутиа Грасиа (командующий 2-м военным округом), Х. Сантос Перальба Гиральдес (командующий ВВС), Ф. Гаутиер Ларраинсар (командующий 1-м военным округом), П. Педроса Собраль (командующий 7-м военным округом), Б. Эрнандес Каррерас (командующий 5-м военным округом), вице-адмиралы Е. Альварес-Аренас Пачеко (командующий ВМС), Р. Кеналь Фернандес (начальник арсенала в Кадисе), Ф.М. Нардис Виаль (командующий войсками на Канарских островах), Р.М. Понсе Кордонес (начальник арсенала в Картагене), Х.М. Собрино де ла Сиерра (начальник арсенала в Ферроле), адмирал Х. Родригес-Гуэрра-и-Альварес-Оссорио (командующий морской зоной Эстрехо).

Социалисты также решительным образом повели наступление на существовавший до них государ- ственный аппарат, в значительной мере состоявший из ненавистных им сторонников Франко, их бывших противников в гражданской войне. У государственных служащих были отняты такие важные привилегии, как право работать неполный день и право на совместительство. Высокопоставленным чиновникам было сокращено жалованье. Многие старые чиновники, а также бывшие франкисты были уволены с государственной службы. Эти меры привели к тому, что государственный аппарат лишился и многих квалифицированных администраторов.

Взамен социалисты наводнили аппарат своими активистами и сторонниками. Испанская соцпартия, тогда численно довольно незначительная (число ее членов составляло лишь $1 \%$ от голосовавших за нее и около 0,5\% всех, принявших участие в выборах), выдвинула на ответственные государственные и административные посты более 50 тыс. своих членов, то есть почти половину от всего своего состава (на 1982 г. ИСРП насчитывала 115 тыс. человек, на 1988 - 220 тыс. $)^{5}$ Кадры эти, впрочем, были в большинстве весьма низкого качества. Дело в том, что образовательный уровень социалистов был крайне скромен: на 1980 г. среди членов ИСРП лица, имеющие среднее и высшее образование составляли только $16 \%$, а к 1986 г. - 22\%, то есть 4/5 имели только начальное образование. И хотя примерно третью часть этих выдвиженцев пришлось вскоре заменить, но большинство осталось в аппарате управления. Следует заметить, что и на региональном уровне социалисты заняли большинство должностей в аппарате управления, так как после выборов 1983 г. ИСРП возглавляла 13 из 17 региональных правительств.

Весьма важным фактором, повлиявшим на изменение состава правящей элиты ${ }^{6}$ Испании стали административные преобразования, следствием которых стало появление новых структур и постов, занимавшихся людьми иного склада. Одно только наличие свободно избираемых Кортесов сыграло в этом огромную роль, поскольку фигура выборного парламентария стала одной из основных и наиболее массовых разновидностей представителя политической элиты страны. Не меньшее значение в этом плане имела децентрализация страны, появление национальных автономий и предоставление им больших полномочий в разных сферах.

${ }^{5}$ Данилевич И.В. Испытание властью... С. 72-73, 91.

${ }^{6}$ К правящей элите автор относит лиц, занимающих положение в структурах государственной власти 
Лица, преимущественно занявшие соответствующие посты в регионах - в органах как законодательной, так и исполнительной власти (особенно в национальных автономиях) были, как и можно было ожидать, выходцами из местных влиятельных кругов или региональных отделений основных политических партий, то есть людьми совершенно иного типа, чем чиновники франкистского режима, и, соответственно, иных социальных характеристик.

Политическая стабильность периода правления социалистов во многом была обеспечена лояльностью предпринимательских кругов. Следует заметить, что политические процессы, вызвавшие большие сдвиги в составе и характеристиках политической элиты, относительно мало сказались на составе элиты экономической (которая всегда меньше зависит от политической конъюнктуры). Верхушка ее в 80-х годах была представлена сложившимися ранее 36 семействами (в частности, такие семьи как А. Гонсало, А. де Эстрады, А. де ла Сота Анчустеги-и-Нардиса, Э. Лопеса, М. Конде, Х. Абелло) общей численностью примерно в 300 человек $^{7}$, занимающих 1,3 тысяч, а с учетом семейных связей контролирующих 3,3 тысяч руководящих постов в административных советах промышленных и банковских монополий ${ }^{8}$.

Повторная победа социалистов на выборах 1986 г. закрепила представление о власти ИСРП в обществе как о наиболее стабильной. Но и ее основной соперник справа - Народный альянс, поставивший перед собой задачу консолидации всех сил, стоящих правее социалистов, достиг весьма впечатляющих успехов - в основном за счет бывшего электората СДЦ. Уже в 1982 г. Народный альянс в союзе с Народно-демократической и некоторыми региональными партиями получил $26,5 \%$ голосов, почти в 5 раз больше (теперь консерваторы имели 106 против 9 мест в нижней палате Кортесов). Его поддержали 40-50\% бывших избирателей СДЦ и две трети ультраправой партии Новая сила (которая после выборов закончила свое существование самороспуском $)^{9}$. В результате выборов 1993 г.

\footnotetext{
${ }^{7}$ Fraga Iribarne M. Despues de la Constitucion y hasio los anos 80. Barcelona, 1979. P. 96.

${ }^{8}$ Понеделко Г.Н. Государство в экономике Испании: взгляд в прошлое и современность. М., 1989. С. 117.

${ }^{9}$ Crisis y cambio: electors y partidos en la Espana de los anos ochenta. Madrid, 1986. P. 357.
}

социалисты у власти опять удержались, однако с еще большей потерей голосов и оказались в зависимости от каталонских и других националистов. В самой ИСРП усилилась внутриэлитная борьба, причем все чаще речь шла о необходимости выдвижения во власть представителей более молодого поколения ${ }^{10}$. Когда же, в виду очевидного прогрессирующего падения популярности социалистов каталонские националисты решили лишить правительство своей поддержки, Ф.Гонсалесу пришлось пойти на еще одни внеочередные парламентские выборы 3 марта 1996 г., проиграв которые, социалисты утратили власть.

Тем не менее, в результате правления социалистов лицо испанской правящей элиты по сравнению с франкистским периодом в целом изменилось очень сильно ${ }^{11}$. Чтобы показать это, рассмотрим ее состав к середине 80-х годов (по состоянию на конец 1984 - начала 1985 гг.) - на момент наивысших успехов социалистов, когда после выборов 1982 г. доля их представителей в испанском истеблишменте была наивысшей. Для этого времени было учтено в общей сложности 1104 представителя испанской политической элиты ${ }^{12}$. Среди них 261 представитель центрального государственного аппарата (министры, помощники министров, генеральные директора и другие руководители структурных подразделений министерств, высокопоставленные чиновники аппарата главы государства и т.д.), 52 мэра, 49 гражданских губернаторов, 102 члена провинциальных правительств, 43 высших деятеля провинциальных парламентов, 16 высших судей, 16 управляющих сберегательными кассами, 318 членов Палаты депутатов и 247 сенаторов (депутаты и сенаторы, занимавшие государственные должности, учтены в соответствующих группах).

Прежде всего, можно отметить, что по-прежнему весьма малая часть членов испанского истеблишмен-

\footnotetext{
${ }^{10}$ Волкова Г.И., Дементьев А.В. Политическая история Испании. М., 2005. С. 118.

11 Социальные характеристики франкистской политической элиты рассмотрены в статье: Волков М.С. Испанская политическая элита периода правления Франко // Исторический журнал: научные исследования, 2013, № 2(14). С. 148-157.

12 Приводимые ниже подсчеты выполнены автором на основе обработки массового биографического материала по: Quien es quien en Espana. Madrid, 1985.
} 


\section{Политика и общество 10 (106) • 2013}

та родилась в столице. Уроженцами Мадрида оказались лишь 92 человека $(8,3 \%)$, причем даже среди высших чиновников центрального аппарата они со-
Сведения о возрастном составе политической элиты (точные даты рождения известны у 1084 ее представителей) приводятся в следующей таблице:

Таблицча 1

Возрастной состав испанской политической элиты на 19852.

\begin{tabular}{|c|c|c|c|c|c|c|c|c|c|c|}
\hline \multirow[t]{2}{*}{ Возраст } & \multicolumn{2}{|c|}{$\begin{array}{l}\text { Центральный } \\
\text { аппарат }\end{array}$} & \multicolumn{2}{|l|}{ Мэры } & \multicolumn{2}{|c|}{$\begin{array}{l}\text { Гражданские } \\
\text { губернаторы }\end{array}$} & \multicolumn{2}{|c|}{$\begin{array}{l}\text { Провинциальные } \\
\text { правительства }\end{array}$} & \multicolumn{2}{|c|}{$\begin{array}{l}\text { Провинциальные } \\
\text { парламенты }\end{array}$} \\
\hline & число & $\%$ & число & $\%$ & число & $\%$ & число & $\%$ & число & $\%$ \\
\hline До 30 & 3 & 1,2 & 3 & 5,8 & - & - & 2 & 2,0 & 1 & 2,3 \\
\hline $30-39$ & 90 & 35,6 & 16 & 30,8 & 23 & 47,9 & 42 & 41,6 & 22 & 51,2 \\
\hline $40-49$ & 115 & 45,5 & 21 & 40,4 & 18 & 37,5 & 43 & 42,6 & 16 & 37,2 \\
\hline $50-59$ & 32 & 12,6 & 9 & 17,3 & 6 & 12,5 & 12 & 11,9 & 3 & 7,0 \\
\hline $60-69$ & 9 & 3,4 & 2 & 3,8 & 1 & 2,1 & 2 & 2,0 & 1 & 2,3 \\
\hline Более 70 & 4 & 1,6 & 1 & 1,9 & - & - & - & - & - & - \\
\hline Всего & 253 & 100 & 52 & 100 & 48 & 100 & 101 & 100 & 43 & 100 \\
\hline
\end{tabular}

Продолжение таблийы 1

\begin{tabular}{|c|c|c|c|c|c|c|c|c|c|c|}
\hline \multirow[t]{2}{*}{ Возраст } & \multicolumn{2}{|l|}{ Судьи } & \multicolumn{2}{|c|}{$\begin{array}{l}\text { Управляющие } \\
\text { сберкассами }\end{array}$} & \multicolumn{2}{|l|}{ Депутаты } & \multicolumn{2}{|l|}{ Сенаторы } & \multicolumn{2}{|l|}{ Всего } \\
\hline & число & $\%$ & число & $\%$ & число & $\%$ & число & $\%$ & число & $\%$ \\
\hline До 30 & - & - & - & - & 8 & 2,6 & 5 & 2,0 & 22 & 2,0 \\
\hline $30-39$ & 1 & 6,3 & 2 & 14,3 & 107 & 34,4 & 52 & 21,1 & 355 & 32,7 \\
\hline $40-49$ & 1 & 6,3 & 4 & 28,6 & 98 & 31,5 & 75 & 30,5 & 391 & 36,1 \\
\hline $50-59$ & 8 & 50,0 & 4 & 28,6 & 69 & 22,2 & 62 & 25,2 & 205 & 18,9 \\
\hline $60-69$ & 4 & 25,0 & 4 & 28,6 & 25 & 8,0 & 37 & 15,0 & 85 & 7,8 \\
\hline Более 70 & 2 & 12,5 & - & - & 4 & 1,3 & 15 & 6,1 & 26 & 2,4 \\
\hline Всего & 16 & 100 & 14 & 100 & 311 & 100 & 246 & 100 & 1084 & 100 \\
\hline
\end{tabular}

ставили только 11,5\% (30 чел.), а в других группах их было еще меньше: среди депутатов - 7,9\% (25 чел.), среди сенаторов - 7,7\% (19 чел.), мэров - 7,7\% (4 чел.), гражданских губернаторов - 8,2\% (4 чел.), членов провинциальных правительств - 5,9\% (6 чел.), деятелей провинциальных парламентов - 7\% (3 чел.), судей - 6,3\% (1 чел.). Заметна разве некоторая разница по этому показателю между сенаторами от разных партий: если среди представителей Народного альянса уроженцы Мадрида составили 14,9\%, то среди социалистов - только 5,9\%, среди же представителей прочих партий их вовсе не было (среди членов Палаты депутатов этот показатель почти не отличается, соответствуя среднему по всей элите).
Очевидно, что состав испанского истеблишмента этого времени отличался исключительной молодостью. Свыше трети всех учтенных лиц были моложе 40 лет, а моложе 50 лет было 70,8\%, тогда как лиц старше 60 лет насчитывалось всего 10\%. Особенно молоды были руководители провинциальных парламентов - среди них к этой возрастной категории относилось 53,5\%, гражданские губернаторы $(47,9 \%)$ и члены провинциальных правительств (43,6\%). Большинство из были представителями ИСРП, а именно социалисты выдвинули во власть наибольшее количество молодежи. Поэтому и члены Палаты депутатов (среди которых лица моложе 40 лет составляли 37\%) были довольно молоды. При этом среди депу- 
татов-социалистов к этой возрастной категории относилось даже более половины - 52\% (среди депутатов от Народного альянса - 15,5\%, прочих - 21,6\%).

Этим же обстоятельством объясняется сравнительная молодость чиновников центрального аппарата (36,8\% моложе 40 лет) и мэров (36,6\%). Среди депутатов от Народного альянса более всего было пятидесятилетних $(42,3 \%)$ и сорокалетних $(22,7 \%)$, депутаты от прочих партий этих возрастов в сумме составляли примерно столько же - около 60\%. Среди сенаторов различия между партиями также были весьма заметны. Если у социалистов моложе 40 была почти треть - 31,1\%, то у «народников» - 9\%, а прочих - 14,3\%. Возраст старше 60 лет имели 20,5\% сенаторов-социалистов, 16,9\% «народников» и $32,2 \%$ сенаторов от прочих партий.

Представители Народного альянса в большей мере, чем ИСРП и других партий были людьми среднего возраста: почти три четверти их составляли сорокалетние $(37,3 \%)$ и пятидесятилетние $(35,8 \%)$, тогда как среди сенаторов-социалистов к среднему возрасту относилось менее половины $(48,4 \%)$, а среди сенаторов от прочих партий $53,6 \%$. Таким образом, сравнительная молодость политической элиты Испании в это время в целом определялась главным образом именно наличием в ней очень большого числа представителей ИСРП.

Рассмотрим теперь образовательные характеристики испанской правящей элиты. Профессиональное образование (главным образом высшее) имели 975 человек $(88,3 \%)$ и 129 человек $(11,7 \%)$ не имели его (или о наличии у них образования в биографии ничего не говорится). Доля последних выше всего среди сенаторов
- 29,1\%, причем преимущественно за счет сенаторовсоциалистов (среди них таких 37,5\%, тогда как среди «народников» 13,4\%, а прочих партий - 21,4\%), а также мэров - 13,5\% (также за счет наличия среди них множества членов ИСРП). Среди остальных групп элиты лиц без специального образования обычно не более $10 \%$ (среди судей, естественно, их вовсе нет). Менее всего таких среди высших чиновников центрального аппарата $(2,7 \%)$ и членов провинциальных правительств (5,9\%). Среди руководителей провинциальных парламентов их 7\%, гражданских губернаторов - 8,2\%, членов Палаты депутатов - 9, $1 \%$ (в том числе среди социалистов 11,8, «народников» 3,9 и прочих партий 10,5\%).

Среди всех учтенных лиц 183 человека $(16,6 \%)$ имели докторские степени по различным наукам. Наивысшая доля докторов - среди судей (50\%; 8 чел.) членов провинциальных правительств (20,6\%; 21 чел.) и высших чиновников центрального аппарата (20,3\%; 53 чел.), то есть среди этих двух категорий политической элиты степень имел каждый пятый. Почти столько же обладателей докторских степеней среди членов Палаты депутатов - 19,5\% или 62 чел. (в том числе среди представителей ИСРП 16,9, «народников» - 25,5\% и прочих партий - 15,8\%). Среди сенаторов докторов было вдвое меньше $8,9 \%$ или 22 чел. (в том числе среди представителей ИСРП 5,9, «народников» - 16,4\% и прочих партий - 7,1\%). Среди мэров их насчитывалось 13,5\% (7 чел.), среди гражданских губернаторов - 8,2\% (4 чел.) и руководителей провинциальных парламентов - 11,6\% (5 чел.).

Данные о характере профессионального образования (учтены только лица, имеющие какое-либо высшее профессиональное образование) дает следующая таблица:

Таблича 2

Состав испанской политической элиты на 1985 2. по профессиональному образованию

\begin{tabular}{|c|c|c|c|c|c|c|c|c|c|c|}
\hline \multirow[t]{2}{*}{ Образование } & \multicolumn{2}{|c|}{$\begin{array}{l}\text { Центральный } \\
\text { аппарат }\end{array}$} & \multicolumn{2}{|l|}{ Мэры } & \multicolumn{2}{|c|}{$\begin{array}{l}\text { Гражданские } \\
\text { губернаторы }\end{array}$} & \multicolumn{2}{|c|}{$\begin{array}{l}\text { Провинциальные } \\
\text { правительства }\end{array}$} & \multicolumn{2}{|c|}{$\begin{array}{l}\text { Провинциальные } \\
\text { парламенты }\end{array}$} \\
\hline & число & $\%$ & число & $\%$ & число & $\%$ & число & $\%$ & число & $\%$ \\
\hline Юридическое & 94 & 37,0 & 15 & 33,3 & 25 & 55,6 & 32 & 33,3 & 18 & 45,0 \\
\hline Экономическое & 67 & 26,4 & 5 & 11,1 & 5 & 11,1 & 22 & 22,9 & 5 & 12,5 \\
\hline Гуманитарное & 16 & 6,3 & 9 & 20,0 & 4 & 8,9 & 11 & 11,5 & 1 & 2,5 \\
\hline Техническое & 37 & 14,6 & 9 & 20,0 & 5 & 11,1 & 19 & 19,8 & 10 & 25,0 \\
\hline Естественное & 19 & 7,5 & 5 & 11,1 & 4 & 8,9 & 10 & 10,4 & 3 & 7,5 \\
\hline Педагогическое & 6 & 2,4 & 2 & 4,4 & 2 & 4,4 & 2 & 2,1 & 3 & 7,5 \\
\hline Прочее & 15 & 5,9 & - & - & - & - & - & - & - & - \\
\hline Всего & 254 & 100 & 45 & 100 & 45 & 100 & 96 & 100 & 40 & 100 \\
\hline
\end{tabular}




\begin{tabular}{|c|c|c|c|c|c|c|c|c|c|c|}
\hline \multirow[t]{2}{*}{ Образование } & \multicolumn{2}{|l|}{ Судьи } & \multicolumn{2}{|c|}{$\begin{array}{l}\text { Управляющие } \\
\text { сберкассами }\end{array}$} & \multicolumn{2}{|c|}{ Депутаты } & \multicolumn{2}{|c|}{ Сенаторы } & \multicolumn{2}{|l|}{ Всего } \\
\hline & число & $\%$ & число & $\%$ & число & $\%$ & число & $\%$ & число & $\%$ \\
\hline Юридическое & 15 & 93,8 & 4 & 26,7 & 127 & 43,9 & 57 & 32,6 & 387 & 39,7 \\
\hline Экономическое & 1 & 6,2 & 7 & 46,7 & 35 & 12,1 & 21 & 12,0 & 168 & 17,2 \\
\hline Гуманитарное & - & - & 1 & 6,7 & 42 & 14,5 & 24 & 13,7 & 108 & 11,1 \\
\hline Техническое & - & - & 2 & 13,3 & 36 & 12,5 & 32 & 18,3 & 150 & 15,4 \\
\hline Естественное & - & - & 1 & 6,7 & 36 & 12,5 & 31 & 17,7 & 109 & 11,2 \\
\hline Педагогическое & - & - & - & - & 12 & 4,2 & 9 & 5,1 & 36 & 3,7 \\
\hline Прочее & - & - & - & - & 1 & 0,3 & 1 & 0,6 & 17 & 1,7 \\
\hline Всего & 16 & 100 & 15 & 100 & 127 & 100 & 175 & 100 & 975 & 100 \\
\hline
\end{tabular}

Наиболее представительную группу среди членов испанского истеблишмента, как видим, составляли лица, получившие юридическое образование - почти $40 \%$. Не считая судей, доля юристов наиболее значительна среди гражданских губернаторов, руководителей провинциальных парламентов и членов Палаты депутатов, причем среди депутатов от Народного альянса юристов насчитывалось почти две трети $-62,2 \%$, тогда как среди депутатов от прочих партий - $58,8 \%$, а среди депутатов-социалистов - значительно меньше - только 29,3\%).

Вторая по значимости группа - лица, получившие образование в сфере экономики, социальных и политических наук - свыше $17 \%$. Таких лиц больше всего среди руководителей сберегательных касс $(46,7 \%)$, высших чиновников центрального аппарата $(26,4 \%)$ и членов провинциальных правительств (22,9\%), среди остальных групп элиты их $11-12 \%$, причем среди сенаторов от различных партий - примерно одинаковый процент, а что касается депутатов, то их явно больше среди депутатов от прочих партий - $17,6 \%$ и меньше среди депутатов «народников» $-8,2 \%$.

Лиц, имевших гуманитарное (историческое, философское, филологическое, искусствоведческое) образование было больше всего среди депутатовсоциалистов - $24,2 \%$ при среднем показателе по депутатам $14,5 \%$ и сенаторов-социалистов $-22,1 \%$ при среднем показателе для сенаторов $13,7 \%$. Это связано с тем, что значительную часть членов ИСРП, делегированных партией в Кортесы, составляла университетская профессура гуманитарного профиля. Среди депутатов и сенаторов от Народного альянса и прочих партий гуманитариев было очень мало (2-5\%).

Лица с техническим и сельскохозяйственным образованием наиболее заметны были среди руководителей провинциальных парламентов $(25 \%)$, членов провинциальных правительств $(19,8 \%)$ и мэров $(20 \%)$; выше среднего доля таких лиц среди сенаторов (особенно от прочих партий, среди которых она составляла $27,3 \%$ ). В целом по численности это третья группа после юристов и экономистов.

Процент тех, кто получил образование в сфеpe естественных и точных наук (в том числе медицинское) выше всего среди сенаторов - 17,7\%, особенно сенаторов от Народного альянса $(20,7 \%$ их имели такое образование). В целом же их немного - чуть больше $11 \%$, причем колебания по отдельным категориям политической элиты невелики. Прочее (специальное военное и дипломатическое) образование имели очень немногие члены политической элиты - около $6 \%$ их было только среди высших чиновников центрального аппарата. Это объясняется тем обстоятельством, что в описываемый период отставных офицеров среди лиц учтенных категорий почти не было, а группа дипломатов в официальном издании этих лет представлена крайне слабо (почему отдельно нами не выделяется).

Что касается предшествующей деятельности представителей испанской правящей элиты, то представляется возможным выделить те же самые 
группы, которые фигурировали в исследовании по началу 1970-х годов. Соответствующие данные имеются по 1098 лицам. Представление о распределении членов политической элиты по этому показателю дает следующая таблица: трального аппарата, окружения главы государства оставались на своих местах, кроме того, и среди членов ИСРП были лица, вступившие в партию сравнительно недавно, а до того служившие в государственном аппарате, наконец, чиновниками

Таблица 3

Состав испанской политической элиты на 1985 г. по предшествующему занятию

\begin{tabular}{|c|c|c|c|c|c|c|c|c|c|c|}
\hline \multirow[t]{2}{*}{$\begin{array}{l}\text { Сфера } \\
\text { деятельности }\end{array}$} & \multicolumn{2}{|c|}{$\begin{array}{l}\text { Центральный } \\
\text { аппарат }\end{array}$} & \multicolumn{2}{|l|}{ Мэры } & \multicolumn{2}{|c|}{$\begin{array}{l}\text { Гражданские } \\
\text { губернаторы }\end{array}$} & \multicolumn{2}{|c|}{$\begin{array}{l}\text { Провинциальные } \\
\text { правительства }\end{array}$} & \multicolumn{2}{|c|}{$\begin{array}{l}\text { Провинциальные } \\
\text { парламенты }\end{array}$} \\
\hline & число & $\%$ & число & $\%$ & число & $\%$ & число & $\%$ & число & $\%$ \\
\hline Госслужба & 140 & 53,6 & 7 & 14,0 & 16 & 32,7 & 27 & 26,5 & 3 & 7,7 \\
\hline Преподавание & 55 & 21,1 & 15 & 30,0 & 13 & 26,5 & 29 & 28,4 & 7 & 17,9 \\
\hline $\begin{array}{l}\text { Иная проф. } \\
\text { деятельность }\end{array}$ & 27 & 10,3 & 11 & 22,0 & 8 & 16,3 & 16 & 15,7 & 13 & 33,3 \\
\hline Частный сектор & 22 & 8,4 & 7 & 14,0 & 6 & 12,2 & 16 & 15,7 & 7 & 17,9 \\
\hline СМИ & 6 & 2,3 & 1 & 2,0 & - & - & 3 & 2,9 & - & - \\
\hline $\begin{array}{l}\text { Общественные } \\
\text { организации }\end{array}$ & 11 & 4,2 & 9 & 18,0 & 6 & 12,2 & 11 & 10,8 & 9 & 23,1 \\
\hline Всего & 261 & 100 & 50 & 100 & 49 & 100 & 102 & 100 & 39 & 100 \\
\hline
\end{tabular}

Продолжение таблийы 3

\begin{tabular}{|c|c|c|c|c|c|c|c|c|c|c|}
\hline \multirow[t]{2}{*}{$\begin{array}{l}\text { Сфера } \\
\text { деятельности }\end{array}$} & \multicolumn{2}{|l|}{ Судьи } & \multicolumn{2}{|c|}{$\begin{array}{l}\text { Управляющие } \\
\text { сберкассами }\end{array}$} & \multicolumn{2}{|c|}{ Депутаты } & \multicolumn{2}{|c|}{ Сенаторы } & \multicolumn{2}{|l|}{ Всего } \\
\hline & число & $\%$ & число & $\%$ & число & $\%$ & число & $\%$ & число & $\%$ \\
\hline Госслужба & 7 & 43,8 & 8 & 50,0 & 76 & 24,0 & 71 & 28,6 & 355 & 32,3 \\
\hline Преподавание & 5 & 31,3 & 1 & 6,3 & 102 & 32,2 & 54 & 21,8 & 281 & 25,6 \\
\hline $\begin{array}{l}\text { Иная проф. } \\
\text { деятельность }\end{array}$ & 4 & 25,0 & 2 & 12,5 & 55 & 17,4 & 47 & 19,0 & 183 & 16,7 \\
\hline Частный сектор & - & - & 5 & 31,3 & 36 & 11,4 & 38 & 15,3 & 137 & 12,5 \\
\hline СМИ & - & - & - & - & 7 & 2,2 & 4 & 1,6 & 21 & 1,9 \\
\hline $\begin{array}{l}\text { Общественные } \\
\text { организации }\end{array}$ & - & - & - & - & 41 & 12,9 & 34 & 13,7 & 121 & 11,1 \\
\hline Всего & 16 & 100 & 16 & 100 & 317 & 100 & 248 & 100 & 1098 & 100 \\
\hline
\end{tabular}

Итак, наиболее часто члены испанской правящей элиты середины 80-х годов были в прошлом связаны с государственной службой. Несмотря на преобладание в новом истеблишменте представителей ИСРП, некоторая часть чиновников цен- в прошлом была заметная часть членов Кортесов от Народного альянса. В общей сложности преимущественно на государственной службе состояли в прошлом 355 человек или треть всего истеблишмента (32,3\%). 


\section{Политика и общество 10 (106) 2013}

Разумеется, эта картина разительно отличается от франкистского периода, когда доля этой группы была почти вдвое - втрое больше - практически она абсолютно господствовала. К середине 80-х годов наиболее широко она была представлена среди высших чиновников центрального аппарата $(53,6 \%)$, судей $(43,8 \%)$ и руководителей сберкасс (50\%). К бывшим чиновникам принадлежала также треть гражданских губернаторов. Среди депутатов на государственной службе в прошлом находилось 24\% (этот показатель не сильно различается по партиям: $24,2 \%$ у социалистов, 21,8 у «народников» и 28,9 у прочих партий), среди сенаторов - 28,6\% (но тут заметная разница между ИСРП с 22,2\% и всеми другими - среди сенаторов-«народников» бывших чиновников $38,8 \%$, от прочих партий - 39,3\%). Меньше всего бывших чиновников среди руководителей провинциальных парламентов - 7,7\% и мэров - 14\%.

Чуть более четверти испанского истеблишмента в прошлом были связаны с преподаванием (почти исключительно это университетская профессура). Выше среднего доля таких лиц среди судей, мэров, руководителей провинциальных парламентов и членов Палаты депутатов, где она составляет треть или около того. При этом среди депутатов от ИСРП профессуры почти вдвое больше, чем депутатов от других партий: 39,9\% против 22,8 у «народников» и $21,1 \%$ у прочих. Заметно ее преобладание и среди сенаторов-социалистов: $25,5 \%$ против 17,9 и $10,7 \%$ соответственно. Заметно ниже доля профессуры среди руководителей провинциальных парламентов (около 18\%) и чиновников центрального аппарата $(21,1 \%)$.

Иной профессиональной деятельностью (в основном частной адвокатской практикой, а также врачебной) занимались около 17\% всей элиты. Наиболее высок этот показатель среди депутатов и сенаторов от Народного альянса (27,7 и 25,4\% при средних показателях по депутатам и сенаторам в 17,4 и 19\% соответственно). Меньше всего таких лиц среди высших чиновников центрального аппарата $(10,3 \%)$.

С частным сектором были связаны 137 человек (12,5\% всех лиц), причем боле всего их было среди руководителей сберкасс $(31,3 \%)$, выше среднего также среди руководителей провинциальных парламентов, членов провинциальных правительств, мэров и сенаторов. Среди депутатов таких было относительно немного, но тут бросается в глаза боль- шой разрыв по партийной принадлежности: среди «народников» их 22,8\% (причем это почти исключительно собственно предприниматели), среди социалистов - 3,4\% (все - наемные служащие), среди депутатов прочих партий - 18,4\%. Среди сенаторов разница меньше $(17,9,13,1$ и 21,4 соответственно, но тенденция та же: представители Народного альянса и прочих партий - почти исключительно предприниматели, социалисты - в основном наемные служащие (хотя среди них было и несколько предпринимателей). Очень немногие представители истеблишмента (лишь $2 \%$ ) в прошлом занимались в основном журналистикой, причем по всем категориям политической элиты показатели примерно одинаковые.

Что касается партийных функционеров, то лиц, известных главным образом по этой прошлой деятельности, относительно немного (11,1\%). Примерно вдвое выше среднего их доля среди руководителей провинциальных парламентов и мэров, несколько выше - среди депутатов и сенаторов, по остальным категориям политической элиты - ниже среднего. Однако бросается в глаза весьма высокая доля партийных функционеров среди депутатов-социалистов - 21,3\% и сенаторов-социалистов - 20,2\% (тогда как среди «народников» их практически вовсе не было). Следует особо отметить, что часть таких активных партийцев, которые были выдвинуты в Кортесы, принадлежала к числу лиц физического труда (их было 26 человек - 7 членов Палаты депутатов и 19 сенаторов, или 2,4\% всей политической элиты); все они были представителями ИСРП.

Новые исторические и политические условия обусловили и существенные отличия характеристик такой небольшой высшей группы правящей элиты, как министры послефранкистских правительств, причем это касается всего периода до конца XX в. Среди министров 1977-2001 гг. четверть (24,6\%) никогда не занимала других высших постов, но более половины $(53,8 \%)$ были депутатами Кортесов и $16,2 \%$ - сенаторами (членами Кортесов при Франко были 12,3\%); на высших административных постах находилось из них меньше лиц, чем министров переходного периода 1975-1977 гг: начальниками департаментов и управлений были 26,9\%, генеральными директорами - 18,5\%, гражданскими губернаторами - 3,1\%, зато 7,7\% были главами региональных правительств. Совсем иную картину, 
чем министры предшествующего переходного периода, демонстрируют министры 1977-2001 гг. и по предшествующим занятиям: офицерами в прошлом были только 2,3\%, чиновниками - 36\%, нотариусами и регистраторами - 3,1\%, адвокатами - 41,5\%, преподавателями университетов - 46,1\%, инженерами $-5,3 \%$, медиками $-0,7 \%$, экономистами $-15,3 \%$, журналистами - 0,7\%, предпринимателями $-10,8 \%$, функционерами общественных организаций $-4,6 \%$ и рабочими - 0,7\%. Практически полностью исчезли среди этой группы представители аристократии: из министров 1975-1977 гг. им был лишь один (3\%), в период 1977-2001 гг. - двое $(1,5 \%)^{13}$.

Посмотрим теперь на социальные характеристики такой группы правящей элиты, как депутаты нижней палаты Кортесов созывов 1979-1993 гг. Средний возраст этой группы менялся мало, при этом процент очень молодых и очень старых лиц уменьшался ${ }^{14}$. Если брать весь состав Кортесов (включая и Сенат, то есть всего 558 человек), то по возрасту он в 1979 г. был несколько старше: до 30 лет $-2,5 \%$, до 40 лет - 33,9\%, до 50 лет $-25,2 \%$, до 60 лет $-17,7 \%$ и старше 60 лет $-10,7 \%{ }^{15}$.

По социальному составу самой заметной группой среди депутатов были преподаватели, доля которых колебалась от четверти до трети (причем в 1979-1982 гг. две трети, а затем более половины их составляла университетская профессура), второй по численности группой были адвокаты, которые в 1979 г. составляли от 15 до 20\% всех депутатов, других специалистов было примерно 12\%, чиновниками были порядка $15 \%$, небольшие группы (с тенденцией к сокращению своей доли) составляли менеджеры и «белые воротнички». Предприниматели были представлены весьма скромно: 1,5\%

${ }^{13}$ Linz J.J., Jerez M., Corzo S. Ministers and regimes in Spain: From the First to the Second Restoration, 18742002 // Who Governs Southern Europe? Regime Change and Ministerial Recruitment, 1850-2000, London: Frank Cass Publishers, 2003. P. 122, 126.

${ }^{14}$ Linz J.J., Gangas P., Jerez M. Spanish Diputados: From the Restoration to Consolidated Democracy // Parliamentary Representatives in Europe 1848-2000. Legislative recruitments and Careers in Eleven European Countries. Ed. by Best H. and Cotta M. Oxford, Oxford University Press, 2000. P. 440.

${ }^{15}$ Campo del S. Social Stratification and Inequality in Spain: The State of the Art // Changing Structures of Inequality: A Comparative Perspective. Quebec, 2003. P. 139.
- 3,5\%, рабочие составляли порядка 5-6\%: Все остальные группы составляли вместе взятые обычно менее $10 \%{ }^{16}$. Из 558 членов Кортесов 1979 г. (включая сенаторов) 30,5\% составляли чиновники, 23,3\% - юристы, 5,2\% - инженеры и архитекторы, 4,8\% - медики, 3,8\% - экономисты, 3,6\% - другие специалисты, 6,5\% - служащие и техники, 13,1\%предприниматели, 4,6\% - рабочие, 4,6\% - прочие и неизвестных занятий ${ }^{17}$.

Если сравнивать депутатов от основных партий этого периода - социалистов и Народного альянса (Народной партии), то социалисты в среднем были несколько моложе - за счет малой численности у них (2-3\%) возрастной группы старше 60 лет, которая у «народников» была довольно значительной. Среди социалистов было относительно меньше юристов, примерно столько же, сколько в среднем по депутатам, чиновников, заметно больше (от 35 до 40\%) преподавателей, совсем нее было предпринимателей и было больше рабочих (порядка 9\%; только в 1993 г. их доля упала до 4,4\%). Среди «народников» отсутствовали «белые воротнички» и первоначально - рабочие (в 1889-1993 гг. они составляли $2-5 \%)^{18}$.

В целом можно констатировать, что политическое развитие Испании после смерти Ф.Франко привело к формированию качественно новой правящей элиты, существенно отличающейся от элиты франкистского режима по основным социальным характеристикам. Она отличалась исключительной молодостью (не только по сравнению с предшествующим периодом, но и объективно), имела заметно отличающиеся от традиционных образовательные характеристики (существенное уменьшение доли лиц, получивших юридическое образование за счет представителей технических, экономических и гуманитарных специальностей), а также отличалась от прежней элиты по предшествующим занятиям ее представителей до достижения ими высоких позиций в государственно-политической сфере. Со-

${ }^{16}$ Linz J.J., Gangas P., Jerez M. Spanish Diputados... P. 442.

${ }^{17}$ Campo del S., Tezanos J.F., Santin W. The Spanish Political Elite: Permanence and Change // Does who governs matter? Elite circulation in contemporary societies, Ed. by Czudnowski M.M. Dekalb (IL), Northern Illinois University Press, 1982. P. 142-143.

${ }^{18}$ Linz J.J., Gangas P., Jerez M. Spanish Diputados... P. 447, 450 . 


\section{Политика и общество 10 (106) • 2013}

кратилось традиционное для Испании абсолютное преобладание военной и гражданской службы за счет увеличения процента лиц, занимавшихся преподавательской и иной профессиональной деятельностью, в том числе и в качестве лиц свободных профессий. Чрезвычайно важным обстоятельством было почти полное вытеснение из состава политической элиты представителей вооруженных сил, всегда прежде игравших там заметную роль.

На рубеже 80-х и 90-х годов то общественное согласие, которое в свое время позволили безболезненно перейти от диктатуры к демократическому режиму и которое продолжало сохраняться в течение первых лет правления социалистов, было нарушено. Случись это раньше, угроза тем принципиальным основаниям, на которых строился новый демократический режим, могла бы быть весьма серьезной. Но это произошло уже в условиях, когда демократизация всех областей жизни в стране стала необратимой, и режим парламентской демократии устоялся и окончательно укоренился. Поэтому утрата власти социалистами уже не могла привести к реставрации прежних форм государственного управления, несмотря на наличие некоторого числа их сторонников.

Историческая роль новой правящей элиты, порожденная приходом к власти социалистов, заключается в том, что, не сумев удержать монополию на власть, она смогла объективно упрочить и консолидировать демократический режим, благодаря которому в свое время пришла к власти. Несмотря на то, что эта элита в очень большой своей части была гораздо менее компетентной в деле государственного управления, чем ее предшественники, и, особенно в первое время, экономическому развитию страны был нанесен значительный ущерб, в долгосрочной перспективе ее правление было оправдано окончательной консолидацией демократии как основы дальнейшего развития испанского общества и государства.

\section{Библиография:}

1. Волков М.С. Испанская политическая элита периода правления Франко // Исторический журнал: научные исследования, 2013, № 2(14).

2. Волкова Г.И., Дементьев А.В. Политическая история Испании. М., 2005.
3. Данилевич И.В. Испытание властью: Испанская социалистическая раболчая партия в 80-е годы. М., 1991.

4. Понеделко Г.Н. Государство в экономике Ис-

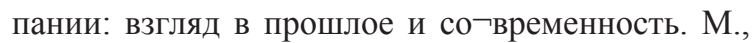
1989.

5. Современная Испания. Отв. ред. В.В.Загладин. M., 1983.

6. Хенкин С.М. Испания после диктатуры. Социально-политические проблемы перехода к демократии. М., «Наука», 1993.

7. Campo del S. Social Stratification and Inequality in Spain: The State of the Art // Changing Structures of Inequality: A Comparative Perspective. Quebec, 2003.

8. Campo del S., Tezanos J.F., Santin W. The Spanish Political Elite: Permanence and Change // Does who governs matter? Elite circulation in contemporary societies, Ed. by Czudnowski M.M. Dekalb (IL), Northern Illinois University Press, 1982.

9. Fraga Iribarne M. Despues de la Constitucion y hasio los anos 80. Barcelona, 1979.

10. Linz J.J., Gangas P., Jerez M. Spanish Diputados: From the Restoration to Consolidated Democracy // Parliamentary Representatives in Europe 1848-2000. Legislative recruitments and Careers in Eleven European Countries. Ed. by Best H. and Cotta M. Oxford, Oxford University Press, 2000.

11. Linz J.J., Jerez M., Corzo S. Ministers and regimes in Spain: From the First to the Second Restoration, 1874-2002 // Who Governs Southern Europe? Regime Change and Ministerial Recruitment, 18502000, London: Frank Cass Publishers, 2003.

12. Quien es quien en Espana. Madrid, 1985.

13. Radiografia de las Nuevas Cortes. Madrid, Sedmay, 1977.

\section{References (transliteration):}

1. Volkov M.S. Ispanskaya politicheskaya elita perioda pravleniya Franko // Istoricheskii zhurnal: nauchnye issledovaniya, 2013, № 2(14).

2. Volkova G.I., Dement'ev A.V. Politicheskaya istoriya Ispanii. M., 2005.

3. Danilevich I.V. Ispytanie vlast'yu: Ispanskaya sotsialisticheskaya rabo $\neg$ chaya partiya v 80-e gody. M., 1991.

4. Ponedelko G.N. Gosudarstvo v ekonomike Ispanii: vzglyad v proshloe i so $\neg$ vremennost'. M., 1989. 
5. Sovremennaya Ispaniya. Otv. red. V.V.Zagladin. M., 1983.

6. Khenkin S.M. Ispaniya posle diktatury. Sotsial'nopoliticheskie problemy perekhoda k demokratii. M., «Nauka», 1993.

7. Campo del S. Social Stratification and Inequality in Spain: The State of the Art // Changing Structures of Inequality: A Comparative Perspective. Quebec, 2003.

8. Campo del S., Tezanos J.F., Santin W. The Spanish Political Elite: Permanence and Change // Does who governs matter? Elite circulation in contemporary societies, Ed. by Czudnowski M.M. Dekalb (IL), Northern Illinois University Press, 1982.
9. Fraga Iribarne M. Despues de la Constitucion y hasio los anos 80. Barcelona, 1979.

10. Linz J.J., Gangas P., Jerez M. Spanish Diputados: From the Restoration to Consolidated Democracy // Parliamentary Representatives in Europe 1848-2000. Legislative recruitments and Careers in Eleven European Countries. Ed. by Best H. and Cotta M. Oxford, Oxford University Press, 2000.

11. Linz J.J., Jerez M., Corzo S. Ministers and regimes in Spain: From the First to the Second Restoration, 1874-2002 // Who Governs Southern Europe? Regime Change and Ministerial Recruitment, 18502000, London: Frank Cass Publishers, 2003. 